\title{
Efektivitas Multi-bi Aid pada Greater Mekong Sub-region (GMS) Triangle Project
}

\author{
Devita Prinanda ${ }^{1}$ \\ devitaprinanda@umm.ac.id.
}

\begin{abstract}
Abstrak
Adanya kedekatan geografis, faktor pendorong, dan faktor menarik menyebabkan intensitas migrasi diGreater Mekong Sub-Region (GMS). Wilayah yang terdiri dari Kamboja, Laos, Myanmar, Thailand, Vietnam, dan sebagian wilayah Cina memiliki banyak permasalahan pada proses migrasi. Permasalahan utama disebabkan oleh tidak adanya kerangka hukum yang mewadahi proses terjadinya migrasi. Sehingga dalam prakteknya banyak migran ilegal dan perdagangan manusia. Penelitian ini akan membahas bantuan yang diberikan oleh Pemerintah Australia (bekerjasama dengan ILO) untuk membantu mengatasi permasalahan migran di GMS.Bantuan tersebut dikategorikan sebagai Multi-bi Aid yaitu bantuan yang diberikan oleh pihak pendonor secara bilateral kepada institusi multilateral. Bantuan tersebut dikeluarkan dalam bentuk sebuah proyek bernama GMS Triangle Project dengan tujuan menciptakan proteksi dalam bermigrasi di GMS. Untuk menganalisa implementasi dari proyek tersebut penulis menggunakan konsep multi-bi aid dan meninjau efektivitas melalui aid effectiveness yang dikemukakan dalam Paris Agreement meliputi ownership, alignment, harmonisation, managing for result, dan Mutual Accountability. Hasil dari penelitian ini memaparkan bagaimana metode multi-bi aid dituangkan dalam bentuk proyek dan efektivitas berbeda pada setiap negara penerima di wilayah GMS.
\end{abstract}

Kata kunci: Multi-bi Aid, GMS Triangle Project, Migrasi, Bantuan Luar Negeri

\begin{abstract}
The existences of geographical factors, push factors and pull factors generated the intensity of migration in Greater Mekong Sub-Region (GMS). The region which consists of Cambodia, Lao PDR, Myanmar, Thailand, Vietnam, and part of China's territory had various problems in the migration process. A predominant problem of migration is rendered by the absence of law framework. Therefore, there were a practically illegal migrant and human trafficking. This research will explain the assistance to recover migration's problems in GMS given by Australian Government (cooperated with ILO). The type of assistance is categorized as multibi aid which is the assistance given by the bilateral donor to a multilateral institution. The assistance was released in the form of a project named GMS Triangle Project with the aim of creating migrant protection in GMS. To analyze the implementation of that project, the author uses the concept of multi-bi aid and review effectiveness through the concept of aid effectiveness proposed by Paris Agreement including ownership, alignment, harmonisation, managing for a result, and Mutual Accountability. The result of this study describes how multibi aid methods are embodied in a form of project and effectiveness are different for each receiving state in GMS.
\end{abstract}

Keywords: Multi-bi Aid, GMS Triangle Project, Migration, Foreign Aid

${ }^{1}$ Korespondensi: Prodi Ilmu Hubungan Internasional. Fakultas Ilmu Sosial dan Ilmu Politik. GKB I Lt.6. Universitas Muhammadiyah Malang, Jl. Raya Tlogomas no. 246 Malang, telp. 0341464318 


\section{Pendahuluan}

Greater Mekong Sub-region (GMS) adalah salah satu sub wilayah di Asia Tenggara yang terdiri dari Kamboja, Laos, Myanmar, Thailand, Vietnam, dan sebagian wilayah Cina khususnya Provinsi Yunnan. GMS disatukan oleh Sungai Mekong yang menciptakan koneksi secara geografis dan ekonomi. Kedekatan geografis serta diikuti faktor pendorong dari dalam negeri dan faktor penarik dari luar negeri menjadikan migrasi di wilayah tersebut meningkat secara signifikan.

Faktor pendorong migrasi di wilayah GMS terdiri dari berbagai macam tergantung pada kondisi domestik masing-masing negara. Myanmar adalah penyumbang migran terbesar di GMS. Faktor pendorong utama migran Myanmar melakukan migrasi eksternal adalah ketidakstabilan politik dan permasalahan etnis. Sehingga banyak pengungsi yang melakukan eksodus ke negara-negara di GMS. Kamboja menyumbang angka migran yang cukup tinggi karena secara ekonomi masih tertinggal dibanding negara lain dan ekonomi nasional hanya terpusat pada wilayah urban. Migran dari Laos pada umumnya juga menjadi pekerja migran untuk mendapatkan peningkatan kualitas hidup. Permasalahan pengangguran di Vietnam adalah faktor pendorong terjadinya migrasi eksternal dengan didukung oleh pemerintah nasional. Sedangkan Thailand dan Cina merupakan negara penerima migran terbesar dari negara-negara GMS. Faktor penarik dari Thailand dan Cina adalah sektor ekonomi yang lebih tinggi dibanding wilayah lainnya. Selain itu terdapat faktor kultural yang menyebabkan terjadinya migrasi seperti pernikahan. Kamboja dan Myanmar menyumbang angka migrasi yang disebabkan oleh pernikahan antar negara (MMN \& AMC, 2013).

Kompleksitas migrasi yang terjadi di GMS menyebabkan beberapa isu transnasional seperti perdagangan dan penyelundupan manusia, pekerja paksa, migran ilegal dan eksploitasi pekerja. Seperti Myanmar contohnya, akibat instabilitas politik di dalam negeri menyebabkan kejahatan transnasional yang melibatkan migran kurang tertangani. Myanmar merupakan sumber dan tempat transit bagi pelaku perdagangan manusia. Tingginya migran yang mencari pekerja di Thailand juga menyebabkan tingginya angka transit dan menjadikan Thailand sebagai tempat perdagangan dan penyelundupan manusia. Terjadinya kejahatan transnasional di GMS disebabkan oleh beberapa faktor. Pertama, tingginya aktivitas migran ilegal. Kedua,isu tersebut juga 
muncul akibat kurangnya kebijakan dan hukum yang mengatur persoalan pekerja migran. Ketiga, kurangnya promosi mengenai proteksi dan keamanan migrasi (Asian Development Bank, 2013).

Pada faktanya sudah terdapat aksi di tingkat nasional, bilateral, ataupun regional dalam mengatasi isu-isu migrasi. Seperti Pemerintah Thailand telah melegalisasi status migran melalui verifikasi nasional pada tahun 2003. Perjanjianperjanjian bilateral yang berkaitan dengan pengentasan perdagangan manusia juga sudah diselenggarakan diantaranya perjanjian antara Thailand dan Myanmar pada 2003, Thailand dan Laos pada 2005, Thailand dengan Vietnam pada 2008, Kamboja dan Vietnam pada 2005, serta Vietnam dan Laos pada 2010. Ditingkat regional telah dibentuk Coordinated Mekong Ministerial Initiative Against Trafficking (COMMIT) pada 2004. Ditingkat ASEAN telah mengimplementasikan Asean Declaration on The Protection and Promotion of the Rights of Migrant Workers (ACMW) pada 2007. Namun pada implementasinya, kerjasama di bidang regional tersebut masih kurang formal dan terbatas (MMN \& AMC, 2013).

Pada 2010, International Labour Organization dengan didanai oleh Pemerintah Australia melalui Australian Aid meluncurkan proyek bernama GMS Triangle Project. Proyek ini bertujuan untuk meningkatkan formulasi dan implementasi praktik migrasi meliputi kebijakan implementasi, rekrutmen pekerja, dan proteksi migran. Proyek ini ditujukan kepada negara-negara berkembang di GMS yaitu Thailand, Kamboja, Vietnam, Laos, Myanmar, dan ditambah dengan Malaysia. Hal ini dikarenakan banyaknya migran GMS yang menjadikan Malaysia sebagai tujuan migrasi dan sebaliknya. Proyek ini berjalan selama 5 tahun dengan melibatkan pemerintah nasional, agensi perekrutan pekerja, organisasi migran dan pekerja, Civil Society Organizations (CSO), serta Non-governmental Organizations (NGO) (ILO, TRIANGLE Project Update: December 2011, 2011).

GMS Triangle Project merupakan bentuk Official Development Assistance (ODA) dari Pemerintah Australia dan bekerjasama dengan ILO. Menelaah definisi ODA yaitu cara untuk membangun negara berkembang melalui bantuan yang diberikan secara bilateral maupun multilateral. Bantuan bilateral adalah bantuan yang diberikan dari negara maju kepada penerima donor secara langsung. Sedangkan bantuan multilateral adalah bantuan yang diberikan oleh institusi multilateral seperti 
Perserikatan Bangsa-Bangsa (PBB) beserta agensinya, Bank Dunia, dan organisasi multilateral lainnya. Pada perkembangannya, untuk menciptakan pembaharuan dan peningkatan pembangunan di negara berkembang maka banyak negara pendonor yang melakukan dukungan kepada institusi multilateral. Sehingga kemunculan terminologi multi-bi aid tidak dapat terelakkan.

Multi-bi aid dapat dikatakan sebagai bentuk gabungan antara bantuan bilateral dan multilateral. Formasi baru dalam pemberian bantuan ini melibatkan multi aktor dalam implementasinya. Multi-bi aid adalah bantuan yang diberikan negara atau kumpulan negara sebagai pendonor (pada umumnya negara maju) kepada institusi multilateral untuk mendanai pembangunan di negara berkembang dengan tema dan wilayah khusus (Reinsberg, The implications of multi-bi financing on multilateral agencies: The example of the World Bank, 2015). Dalam GMS Triangle Project negara dapat dikategorikan sebagai multi-bi aid dimana negara pendonor yaitu Australia melalui Australian Aid memberikan dana kepada ILO untuk mengentaskan permasalahan migrasi di GMS yang dominasi anggotanya adalah negara berkembang.

Selanjutnya, penelitian ini membahas implementasi multi-bi aid dalam GMS Triangle Project. Analisa yang digunakan adalah efektivitas dari kegiatan multibi aid untuk melihat efisiensi dari bentuk baru dalam pemberian bantuan.

\section{Tinjauan Pustaka}

Tinjauan pustaka dalam penelitian ini menggunakan dua konsep yaitu Multi-bi Aid dan Aid Effectiveness. Keduanya digunakan untuk menjawab pertanyaan bagaimana implementasi Multi-bi Aid dalam GMS Triange Project.

\section{Multi-bi Aid}

Konsep pertama yang digunakan sebagai alat analisa dalam penulisan ini adalah Multi-bi Aid. Tidak seperti bantuan multilateral, multi-bi aid mengkoneksikan pendonor dengan agensi multilateral melalui trust fund. Trust fund adalah instrumen keuangan untuk dana pembangunan yang dikelola oleh pihak (pada umumnya) organisasi multilateral yang mana dananya harus terpisah dengan organisasi inti. Trust fund harus mengikuti persyaratan berupa laporan yang diminta oleh pendonor. Multibi aid selanjutnya dapat digunakan untuk mendanai salah satu dari proyek institusi 
multilateral. (Reinsberg, The implications of multi-bi financing on multilateral agencies: The example of the World Bank, 2015)

Selain untuk pembangunan negara berkembang, multi-bi aid dapat memberikan keuntungan bagi pendonor dan institusi multilateral. Bagi pendonor, apabila pendonor adalah negara, maka negara tersebut dapat menyebarkan pengaruh di wilayah yang sebelumnya mereka kurang memiliki pengaruh. Menjadi suatu keuntungan bagi negara pemberi donor baik tunggal maupun non-tunggal karena melalui multi-bi aid negara bebas menentukan wilayah yang dituju dan tema khusus. Walaupun institusi multilateral yang diajak untuk bekerjasama memiliki mandat secara global, akan tetapi negara berhak menentukan tujuan yang diinginkan. Bagi institusi multilateral, cara ini bermanfaat untuk membantu ketidakmampuan institusi dalam berbagai aspek seperti keterbatasan pengambilan keputusan, keterbatasan institusional, dan dengan adanya donor maka dapat memberikan pengaruh yang lebih baik dalam proyek-proyek institusi (Reinsberg, 2017).

Namun, pada praktiknya multi-bi aid juga dapat memberikan kelemahan dan kerugian dalam aktivitas penyaluran dana. Multi-bi aid dapat menjadi rapuh jika pendonor menggunakan tujuan utamanya untuk kepentingan nasional negara. Sehingga tujuan utama pembangunan negara berkembang terdistorsi dengan kepentingan pendonor. Kegiatan ini juga dapat dikatakan sebagai politisasi dalam bantuan. Selain itu, biaya administrasi yang tinggi karena banyaknya aktor yang terlibat dalam perjanjian untuk memberikan bantuan dapat menurunkan efektivitas dari multibi aid. Sehingga dalam hal ini arus keuangan tidak dapat diprediksi (Gulrajani, Bilateral versus multilateral aid channels: Strategic choices for donors, 2016).

\section{Aid Effectiveness}

Efektivitas pendonor dalam memberikan bantuannya mengacu pada Paris Declaration on Aid Effectiveness. Efektivitas tidak terlepas dari performansi pendonor dan dinamika organisasi yang menjalankan. Empat hal yang mempengaruhi efektivitas bantuan adalah lingkungan politik, pemerintahan pemberi donor, tujuan organisasi, dan kebijakan dalam mengelola insentif. Sehingga proses input sangat mempengaruhi bagaimana eksekusi donor dilakukan (Gulrajani, 2014).

Penjabaran efektivitas dalam pemberian bantuan sesuai dengan Paris Declaration terbagi dalam lima indikator yaitu: 
a. Ownership

Negara berkembang harus memiliki kebijakan dan strategi perkembangan nasional yang efektif. Sedangkan pendonor harus menghormati kepemimpinan negara berkembang dan memperkuat kemampuan dalam memberikan bantuan.

b. Alignment

Penyesuaian antara program pendonor dengan strategi pembangunan dan kebijakan nasional negara berkembang harus diutamakan. Penyesuaian diwujudkan dengan dialog kebijakan antar kedua partisipan, pendanaan yang tertuju pada kondisi yang didasari oleh strategi pembangunan nasional, menggunakan lembaga negara dan prosedur negara penerima donor, kerjasama antara penerima donor dan pemberi donor dalam membentuk kerangka kerja yang disepakati bersama, penerima donor melakukan reformasi dan menanamkan asas keberlanjutan, dan sistem transparansi mengenai progres yang berkesinambungan dengan pembangunan nasional. .

\section{c. Harmonisation}

Harmonisation adalah keselarasan dengan membentuk koordinasi antara penerima dan pemberi bantuan. Koordinasi menerapkan rencana, pembagian kerja, pelaksanaan program, dan penyelarasan prosedur. Secara teknis harmonisasi juga diperlukan analisis dampak lingkungan, penegakan hukum, dan penyelarasan isu lintas sektoral seperti kesetaraan gender.

d. Managing for Result

Orientasi pada hasil dalam mengelola dan mengimplementasikan bantuan. Seluruh pihak diharuskan memperhatikan hasil program sesuai dengan capaian dan strategi nasional serta berdampak positif. Seluruh pihak bekerjasama dengan pendekatan partisipatif untuk memperkuat kapasitas dan hasil dari implementasi bantuan.

e. Mutual Accountability

Adanya pertanggung jawaban kepada seluruh pihak baik pemberi bantuan dan penerima bantuan untuk pengembangan sumber daya. Sumber daya yang dimaksud adalah anggaran. Anggaran dipertanggungjawabkan melalui laporan keuangan yang sesuai dengan implementasi dan berkesinambungan dengan strategi nasional. 
Metode

Tipe penelitian ini adalah kualitatif deskriptif. Teknik pengumpulan data menggunakan studi literatur dengan sumber laporan resmi, jurnal, penelitian, dan berita. Hasil penelitian didapatkan dari melakukan analisis terhadap sumber data kemudian disederhanakan agar dapat dipahami dengan mudah. Setelah itu data dikorelasikan dengan konsep yang ada untuk dioperasionalisasikan menjadi hasil dan pembahasan yang spesifik.

\section{Hasil dan Pembahasan}

Untuk memahami secara komprehensif mengenai implementasi Multi-bi aid pada GMS Triangle Project, maka pembahasan ini akan dibagi menjadi dua sub bahasan yaitu menelaah GMS Triangle Project sebagai Multi-bi Aid dan efektivitas GMS Triangle Project dalam mengatasi pekerja migran di wilayah GMS.

\section{Menelaah GMS Triangle Project sebagai Multi-bi Aid}

GMS Triangle Project merupakan proyek yang didanai oleh Pemerintah Autsralia di bawah Department of Foreign Affairs and Trade(DFAT). Melalui program Australian Aid pemerintah Australia menggelontorkan dana sebesar 9.400.000 Dolar dengan tujuan utama memperkuat formulasi dan implementasi perlindungan dan keamanan pekerja migran di wilayah GMS meliputi Kamboja, Myanmar, Laos, Thailand, Vietnam dan negara tetangga Malaysia. Program ini berjalan selama lima tahun sejak April 2010 hingga Juli 2015 (DFAT, 2015).

Program ini memiliki tiga tujuan khusus yang merupakan cakupan dari tujuan utama. Pertama adalah memperkuat perekrutan migran dan kebijakan perlindungan pekerja migran yang mendukung kepentingan tripartit dan fokus kepada permasalahan gender. Kedua adalah kemampuan tripartit untuk terlibat hingga tidak terdapat kesenjangan antara kebijakan nasional, perjanjian bilateral, dan komitmen regional terkait perekrutan dan proteksi pekerja migran baik pria maupun wanita (DFAT, 2015).

Pihak yang terlibat dalam projek ini adalah DFAT sebagai pendonor, ILO sebagai institusi multilateral, dan organisasi pendukung kegiatan. ILO merupakan lembaga spesialis yang berada di bawah naungan Perserikatan Bangsa-Bangsa (PBB). PBB merupakan organisasi internasional yang bersifat multilateral berdasarkan anggota 
negaranya. Sehingga ILO dapat dikategorikan orbagai organisasi multilateral dengan tujuan menngatur permasalahan buruh secara global. Pihak ILO yang terlibat meliputi ILO Technical Unit dan administrative unit. Sedangkan organisasi pendukung kegiatan meliputi Civil Society Organizations (CSO), lembaga perekrutan, persatuan pekerja, dan partisipan lainnya.

GMS Triangle Project mencakup beberapa kegiatan dengan melakukan pendekatan langsung kepada pemerintah nasional, CSO, dan migran, pekerja migran, beserta keluarganya. Tercatat pada pembaharuan laporan yang diterbitkan oleh ILO pada Januari 2015, proyek ini telah memberikan dukungan kepada 51.734 migran, masyarakat yang berpotensi menjadi migran, beserta keluarganya. Dukungan dilakukan dengan agenda konsultasi, konseling, pelatihan, informasi melalui media masa, dan capacity building. GMS Triangle Project juga terlibat dalam penyusunan regulasi terkait pekerja migran di masing-masing negara yang didasari oleh prinsip hak asasi manusia. Disamping itu, untuk pemerintah di masing-masing negara juga mendapatkan pelatihan untuk pelaksanaan dan pengamanan migrasi. Tercatat hingga akhir proyek di tahun 2015 terdapat 2.259 pegawai pemerintah nasional dan 9.020 pejabat publik di level lokal mendapatkan pelatihan. Pelatihan juga diberikan kepada 20 CSO dalam rangka capacity building (ILO, 2015). Bentuk kegiatan lain dalam proyek ini adalah promosi mengenai keselamatan migran dengan menyelenggarakan acara dan kampanye yang berkaitan dengan tema. Untuk memfasilitasi permasalahan dan komplain dari migran, maka proyek ini juga membantu memberikan kompensasi atas kecelakaan kerja dengan total biaya yang telah disalurkan sebanyak 2 Juta Dolar (ILO, 2015).

Sesuai dengan penjelasan Reinsberg bahwa dalam multi-bi aid, pemberi donor berkontribusi pada organisasi multilateral untuk tujuan tertentu (Reinsberg, 2017). Dalam kasus ini, DFAT merupakan bagian dari Pemerintah Australia berkontribusi pada ILO selaku organisasi multilateral untuk proteksi migrasi di wilayah GMS. Kontribusi dilakukan berupa pemberian dana bantuan kepada ILO sebesar 9.400.000 Dolar. Dana tersebut dikelola ILO yang selanjutnya juga dapat dikatakan sebagai trust fund. Pertanggung jawaban dana dilakukan dengan memberikan laporan secara berkala dan adanya evaluasi dari DFAT. 
Dampak yang didapat setelah seluruh proyek dilaksanakan dan dievaluasi meliputi kebijakan dan implementasi. Masing-masing negara telah menyelesaikan instrumen kebijakan yang sesuai dengan standar global.

\section{Efektivitas GMS Triangle Project dalam Mengatasi Pekerja Migran di Wilayah GMS}

Berdasarkan efektivitas bantuan yang dikemukakan oleh Paris Agreement pada sub pembahasan ini akan membahas secara komprehensif mengenai masingmasing indikator efektivitas bantuan. Ownership, Alignment, Harmonisation, Managing for Result, dan Mutual Accountability akan dioperasionalisasikan berdasarkan bukti-bukti yang dipaparkan dalam laporan reguler dan akhir oleh ILO dan DFAT.

a. Ownership

Indikator ini menjelaskan bahwa penerima donor harus memiliki strategi perkembangan nasional yang efektif dan pemberi bantuan mendukung perkembangan tersebut. Dalam kasus migrasi di GMS, pada dasarnya pemerintah masing-masing negara telah memiliki komitmen untuk menciptakan migrasi yang aman dan teratur. Sesuai yang telah dijelaskan di latar belakang, melalui COMMIT dan ACMW pemerintah di wilayah GMS telah memberikan perhatiannya terhadap masalah migrasi.

Melalui GMS Triangle Project pemerintah masing-masing negara memiliki kontribusi untuk meningkatkan perkembangan nasional di bidang migrasi. Di Kamboja, Ministry of Labour terlibat dalam pelatihan untuk para migran sebelum berangkat. Kemudian dikeluarkannya prakas berdasarkan isu migrasi oleh kementerian nasional Kamboja. Pada tahun 2013 Ministry of Labour and Vocational Training (MOVLT) mengeluarkan delapan prakas. Prakas adalah kebijakan yang dikeluarkan oleh kementerian atau Gubernur Bank Nasional di Kamboja (ADB, 2018). Delapan prakas dikeluarkan sebagai penentuan standar dalam agen perekrutan, proteksi terhadap pekerja migran, dan komplain oleh migran (ILO, 2014). Salah satu contoh prakas yang dikeluarkan oleh Pemerintah Kamboja adalah mengenai pembayaran kompensasi oleh agen perekrutan. Dalam hal ini GMS Triangle Project memberi dukungan kepada MOLVT untuk melakukan sosialisasi mengenai mekanismemekanisme dalam bermigrasi (ILO, 2014). 
Di Laos, kementerian yang terlibat dalam proyek adalah Ministry of Labour and Social Welfare (MOLSW), Ministry of Foreign Affair (MOFA), Ministry of Public Security (MOPS). Bantuan diberikan kepada pemerintah Laos dalam rangka menyusun dan mengimplementasikan keamanan dalam bermigrasi. Sehingga pemerintah memiliki program antisipasi terhadap keamanan migran melalui hukum migrasi baru yang sedang berjalan (ILO, 2014).

Di Vietnam, kementerian yang terlibat adalah Ministry for Labour, Invalids, and Social Affairs (MOLISA). MOLISA terlibat dalam kegiatan lokakarya terkait dengan keamanan sosial. Selain itu pemerintah Vietnam menggunakan bantuan dari proyek tersebut untuk dapat meratifikasi ILO’s Migrant Workers Convention.

Di Thailand, Ministry of Labour berfungsi mengadopsi kebijakan kebijakan tentang pekerja di industri perikanan (DFAT, 2015). Pemerintah Thailand memiliki program untuk mengembangkan pedoman dalam melakukan inspeksi terhadap kapal penangkap ikan yang dilakukan di bawah Department of Labour Protection and Welfare (ILO,2015).

b. Alignment

Proyek dilaksanakan berdasarkan hasil kerjasama dan dialog yang dilakukan untuk keselarasan antara tujuan GMS Triangle Project dan pemerintah nasional. Kerjasama kemudian dilanjutkan dengan kesepakatan-kesepakatan sebagai bentuk penyesuaian proyek dan perkembangan nasional. Dalam salah satu laporan yang diterbitkan oleh ILO disebutkan bahwa strategi utama dalam proyek ini adalah mendukung mekanisme hukum nasional, sehingga proyeknya-pun menyesuaikan kepentingan nasional (ILO, 2013). Dengan ini maka terbentuk upaya-upaya penyesuaian antara pemberi donor, organisasi, pemerintah nasional, dan organisasi lain yang terlibat.

Salah satu bentuk dialog antara ILO dengan Pemerintah Thailand terkait dengan meningkatkan praktik kerja pekerja migran dalam industri perikanan adalah mendukung terbentuknya regulasi untuk usia pekerja di industri perikanan minimum 18 tahun (ILO, 2015). Bentuk dialog lain dilakukan dengan Pemerintah Malaysia adalah enam diskusi yang dilaksanakan dalam tiga tahun mengenai proteksi pekerja migran. Proteksi dilakukan berdasarkan program pemerintah mengenai pengembangan pedoman dalam inspeksi kapal. Proyek tersebut kemudian membantu kordinasi 
dengan pemerintah Thailand untuk menyetujui indikator SMART (Spesific, measurable, achievable, relevant, time-bound) dalam pedoman tersebut. Selain itu, terdapat kerjasama antara tim proyek dengan Department of Employement pada 2011 untuk merencanakan kerangka kerja selama dua tahun ke depan dalam proses rekrutmen migran. Kerangka kerja tersebut merupakan bentuk harmonisasi untuk keberhasilan proyek rekrutmen di sektor perikanan (ILO, 2011).

Di Laos, diselenggarakan Labour Migration Network Meeting yang merupakan forum pertama yang membahas mengenai tata kelola pekerja migran (ILO, 2015). Selain itu juga terdapat kordinasi yang dilakukan di tingkat supranasional. Salah satunya seperti koordinasi dengan Australia-Asia Program to Combat Trafficking in Persons (AAPTIP) juga melibatkan GMS Triangle Project untuk mendapatkan relasi untuk menangani permasalahan human trafficking secara menyeluruh di wilayah Asia Tenggara. GMS Triangle Project juga kerjasama dengan UN Women untuk mengatasi permasalahan eksploitasi perempuan(ILO, 2015). GMS Triangle Project juga melakukan dialog pada forum global mengenai eksploitasi pekerja dan pekerja paksa (ILO, 2015).

\section{c. Harmonisation}

Harmonisasi dibentuk dengan koordinasi pelaksanaan dan penyelarasan prosedur. Dalam GMS Triangle Project, pelatihan merupakan bentuk penyelarasan hukum dan prosedur pelaksanaan migrasi yang sesuai dengan standar global. Di Laos, terdapat pelatihan mengenai manual emigrasi yang didukung oleh Kementerian Pekerja dan Kesejahteraan Sosial. Sedangkan di Thailand, terdapat pelatihan untuk pengawas pekerja dalam industri perikanan di 22 wilayah pesisir di Thailand. Sementara itu, di Kamboja, Laos, dan Vietnam terdapat pelatihan untuk migran sebelum berangkat.

Koordinasi dilakukan sebagai bentuk harmonisasi antara program pemerintah dan proyek yang dilaksanakan oleh GMS Triangle Project maupun harmonisasi antar negara dalam GMS. Untuk harmonisasi antar penerima donor di wilayah GMS diselenggarakan beberapa Memorandum of Understanding (MoU). Contoh MoU antara lain adalah MoU antara Thailand dan Myanmar dalam bidang kerjasama pekerja, MoU antara Malaysia dan Myanmar mengenai pekerjaan dan pekerja domestik, serta publikasi hasil penelitian mengenai efektivitas MoU untuk membahas manajemen buruh di wilayah Thailand dan negara tetangganya. 
Pertemuan dalam rangka kordinasi antara ILO dan negara di GMS juga diselenggarakan sebagai bentuk koordinasi. Dengan bantuan ILO, di myanmar juga menyelenggarakan Meeting of Civil Society Network for Migrants. Beberapa advokasi juga dilakukan ILO dan seperti advokasi dengan malaysia terkait dengan permasalahan pekerja migran advokasi dengan thailand terkait dengan meningkatkan praktik kerja migrant worker dalam industri perikanan terutama mendukung terbentuknya regulasi untuk usia pekerja di industri perikanan minimum adalah 18 tahun (ILO, 2015).

Agar terdapat harmonisasi antara proyek dengan pemahaman masyarakat maka terdapat program penyebaran informasi melalui berbagai macam cara. Penyampaian pesan dengan tema safe migration dilaksanakan melalui kegiatan pada Hari Migrasi Internasional. Terdapat juga penyebaran informasi melalui program yang ditayangkan oleh stasiun nasional di Vietnam yaitu program voice of vietnam channel. Sedangkan di Laos, pesan-pesan tentang migrasi disampaikan melalui pemutaran film di televisi nasional (ILO, 2015). Di Thailand juga dilakukan kampanye Saphan Siang yaitu kampanye untuk meningkatkan kesadaran masyarakat terhadap isu-isu migrasi meliputi hak-hak migran, kesetaraan, dan potensi migran dalam kehidupan ekonomi dan sosial (ILO, 2014).

Penyelarasan juga tidak hanya dilakukan dengan pemerintah nasional tapi juga kepada organisasi pekerja atau persatuan pekerja. Pihak persatuan pekerja yang terlibat adalah Lao Federation of Trade Unions (LTFU), Malaysian Trade Union Congress (MTUC), Vietnam General Confederation of Labour (VGCL), Labour Congress of Thailand (LCT), Thai Trade Union Congress (TTUC), dan Cambodian Labour Confederation (CLC) (ILO, 2011). Persatuan pekerja berfungsi untuk memberikan informasi, menyediakan bantuan hukum, memperkuat proteksi migran, dan melakukan kolaborasi lintas batas dengan persatuan pekerja lainnya. Seperti pada tahun 2015, VGCL melakukan penandatanganan MoU dengan MTUC sebagai bentuk capacity building jangka panjang sebagai pendukung pemerintah dalam isu-isu migrasi (ILO, 2013).

d. Managing for Result

Hasil yang didapat dari GMS Triangle Project terbagi menjadi dua garis besar. Pertama adalah kerangka hukum, legislatif, atau kebijakan. Kedua adalah implementasi dan dampak yang ditimbulkan. Instrumen kebijakan yang telah 
difokuskan pada setiap negara memiliki progres dan hasil yang berbeda. Di Kamboja proyek ini kerangka kebijakan mengarah pada proteksi persamaan gender yang telah disusun dengan naik. Di Thailand telah diadopsi kebijakan mengenai proteksi migran pada industri perikanan. Di Vietnam telah disahkan mengenai peraturan batasan pembayaran deposit yang harus dibayarkan oleh pekerja migran pada tahun 2013. Namun, di Vietnam terdapat kebijakan lainnya yang tidak dapat dikonsultasikan dan diselesaikan tepat waktu dalam masa kerja proyek tersebut. Di Laos, hukum pekerja migran khususnya hukum mengenai rekrutmen disusun dengan beberapa masukan dari ILO dan tim proyek ini, namun hukum tersebut belum disahkan oleh pemerintah Laos sehingga yang dijalankan hanya kebijakan untuk mengatasi pergadangan manusia. Di Malaysia, GMS Triangle Project memberikan komentar dalam penyusunan kebijakan tentang badan agen tenaga kerja swasta (DFAT, 2015). Adapun bantuan teknis yang diberikan kepada Malaysia adalah untuk penyusunan Private Employement Agencies Bill and Regulation on Domestic Work (ILO, 2014).

Sama halnya dengan kerangka kebijakan, implementasi dari GMS Triangle Project beragam pada masing-masing negara. Di Kamboja dibentuk kelompok khusus untuk melakukan tinjauan dan inspeksi terhadap proses rekrutmen pekerja migran oleh agen swasta. Selain itu proyek ini juga melakukan pemberlakuan mekanisme suspensi terhadap agensi jika tidak sesuai dengan ketentuan. Dampak positif dari implementasi ini adalah agensi rekrutmen pekerja menaati peraturan yang ada, dimana pemerintah dan persatuan buruh tidak menyangka bahwa dengan proyek ini dapat menimbulkan kepatuhan bagi agensi perekrutan.

Sebagai bentuk implementasi dari proyek, di Kamboja juga telah dibentuk Migrant Worker Resource Center (MRC) untuk lembaga penerima komplain dari pekerja migran. Sebelumnya, NGO di Kamboja kurang bisa mengatasi permasalahan komplain migran. MRC juga didirikan di Myanmar, Laos, dan Vietnam (ILO, 2014).

e. Mutual Accountability

Mengenai akuntabilitas dari bantuan yang diberikan, baik pihak organisasi multilateral dan pemberi donor telah memaparkan laporan atas kegiatan yang telah dilaksanakan. ILO memaparkan laporan secara rutin dengan tema project update. Project update di terbitkan pada Desember 2011, Juni 2012, Juni 2013, Januari 2014, 
Juni 2014, Januari 2015, dan Oktober 2015. Masing-masing laporan yang diterbitkan menjelaskan luaran yang didapat secara kualitatif dan kuantitatif.

Secara kualitatif telah dideskripsikan pada indikator managing for result. Sedangkan data data kuantitatif yang dipaparkan pada laporan terakhir yaitu Oktober 2015 memaparkan kuantitas penerima bantuan. Laporan tersebut menyebutkan bahwa hasil dari 5 tahun proyek berlangsung adalah adanya 18 rekomendasi kebijakan, pelatihan yang telah diberikan kepada 20.083 stakeholder, dengan rincian di level nasional sebanyak 6.221 stakeholder, di level lokal telah sebanyak 13.862 stakeholder. Sebanyak 61.991 migran telah diberikan bantuan dengan rincian 36.595 untuk migran yang potensial dan 22.936 untuk migran di negara tujuan. Sebanyak 6.240 komplain dan permasalahan telah diatasi dengan nominal 2 juta dolar yang dikeluarkan untuk membayar kompensasi atas komplain yang diajukan oleh migran (ILO, 2015).

Keberlanjutan juga merupakan bagian dari adanya akuntabilitas dalam sebuah proyek. Bentuk keberlanjutan dilakukan dengan proses pemantauan. Di vietnam dilakukan pemantauan terhadap 10 agensi perekrutan pekerja oleh Vietnamese Association of Man Power Supply (VAMAs). VAMAs memantau metode wawancara dan pelatihan migran sebelum berangkat (ILO, 2015).

\section{Kesimpulan}

GMS Triangle Project merupakan multi-bi aid oleh Australia dan ILO sebagai organisasi multilateral. Upaya baru dalam memberikan bantuan kepada negara berkembang diwujudkan dengan sistem multi-bi aid ternyata memiliki dampak yang signifikan. Multi-bi aid sebagai upaya alternatif dalam memberikan bantuan dapat mencerminkan kepentingan suatu negara dalam wilayah tertentu sehingga bantuan dapat ditujukan secara efektif. Bantuan dalam GMS Triangle-project mendukung masyarakat di GMS untuk bermigrasi secara legal. Laporan terakhir dari ILO menyebutkan 89\% masyarakat di GMS memilih untuk menjadi migran legal setelah ada program tersebut. Data ini membuktikan efektifitas bantuan dari multi-bi aid. Dukungan dan keterlibatan pemerintah nasional menjadi kunci utama berhasilnya sebuah bantuan. Bagaimanapun implementasi akan diterapkan pada level domestik dengan pengawasan pemerintah. Di GMS, pemerintah nasional masih belum mampu untuk menyusuk kebijakan dan hukum yang kuat bagi migran, sehingga dengan adanya 
GMS Triangle Project maka dapat memperkuat keinginan pemerintah untuk melakukan proteksi terhadap migran.

\section{Daftar Rujukan}

\section{Buku}

MMN \& AMC. (2013). Migration in The Greater Mekong Subregion Resource Book. Chiang Mai: Mekong Migration Network \& Asian Migrant Center.

Jurnal\& Artikel

Gulrajani, N. (2014). Organizing for donor effectiveness: an analytical framework for improving aid effectiveness. Development Policy Review.

Gulrajani, N. (2016). Bilateral versus multilateral aid channels: Strategic choices for donors. ODI.

Reinsberg, B. (2015). The implications of multi-bi financing on multilateral agencies: The example of the World Bank. Center for Comparative and International Studies.

Reinsberg, B. (2017). five steps to smarter multi-bi aid, A new way forward for earmarked finance. Overseas Development Institute.

\section{Laporan}

Asian Development Bank. (2013). Facilitating Safe Labor Migration in The Greater Mekong Subregion. Philippines: Asian Development Bank.

DFAT. (2015). ILO Evaluation. Department of International Affair and Trade.

ILO. (2013). Evaluation Summary Tripartite Action to Protect Migrants within and from the GMS from Labour Exploitation (TRIANGLE) project. ILO.

ILO. (2013). GMS TRIANGLE: Working With Trade Unions to Protect Migrant Workers. ILO.

ILO. (2011). TRIANGLE Project Update: December 2011. ILO.

ILO. (2014). GMS TRIANGLE Project Update: April 2014. ILO.

ILO. (2014). GMS TRIANGLE Project Update: Juni 2014. ILO.

ILO. (2015). GMS Triangle Project Update: January 2015. ILO.

ILO. (2015). GMS TRIANGLE Project Update: October 2015. International Labour Organizations. 


\section{Website}

ADB. (2018). Glossary Definition. Retrieved from Asia Bonds Online: https://asianbondsonline.adb.org/regional/guides/definition.php?term =Prakas diakses pada 1 Agustus 2018. 